\section{UJMM

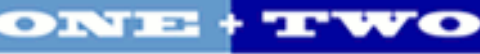

Volume 4 | 2012 Spring

\section{Undergraduate Journal of Mathematical}

Modeling: One + Two

2012

\title{
U.S. Oil Reserves and Peak Oil
}

Trang Luong

University of South Florida

Advisors:

Arcadii Grinshpan, Mathematics and Statistics

Scott Campbell, Chemical \& Biomedical Engineering

Problem Suggested By: Scott Campbell

Follow this and additional works at: https://digitalcommons.usf.edu/ujmm

Part of the Mathematics Commons

UJMM is an open access journal, free to authors and readers, and relies on your support:

Donate Now

\section{Recommended Citation}

Luong, Trang (2012) "U.S. Oil Reserves and Peak Oil," Undergraduate Journal of Mathematical Modeling: One + Two: Vol. 4: Iss. 2, Article 1.

DOI: http://dx.doi.org/10.5038/2326-3652.4.2.1

Available at: https://digitalcommons.usf.edu/ujmm/vol4/iss2/1 


\title{
U.S. Oil Reserves and Peak Oil
}

\begin{abstract}
We use calculus methods to estimate the quantity of U.S. oil reserves. We consider a model that consists of an exponential function with four unknown constants. We fit real oil production data to determine the unknown constants. With the constants determined we use the function to find the year in which the U.S. oil production reached its peak. We also estimate the amount of petroleum produced until the end of 2006 , and the undiscovered oil reserves to be produced in the future.
\end{abstract}

\section{Keywords}

Oil Reserves, Peak Oil Production, Conservation

\section{Creative Commons License}

\section{(c) (i) (3)}

This work is licensed under a Creative Commons Attribution-Noncommercial-Share Alike 4.0 License. 


\section{TABLE OF CONTENTS}

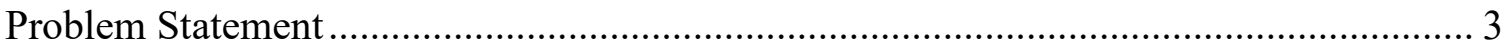

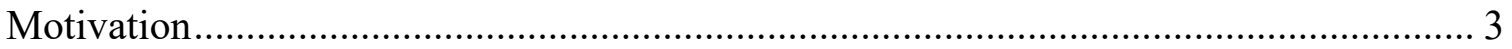

Mathematical Description and Solution Approach................................................. 4

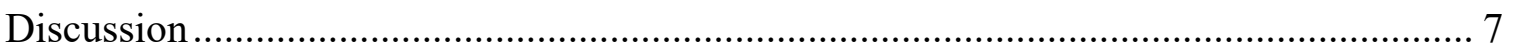

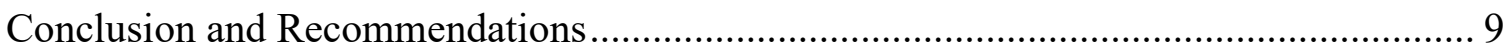

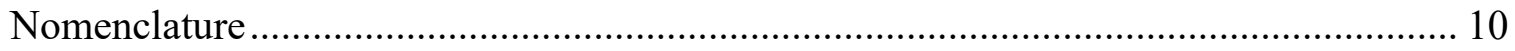

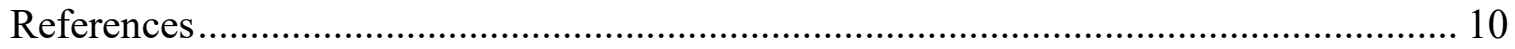

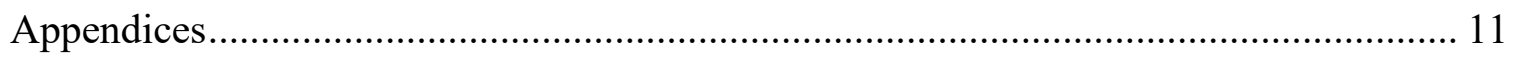




\section{PROBLEM STATEMENT}

In 1956, M. King Hubbert, an American geologist, postulated that US oil reserves are finite and he predicted that the oil productions would reach a maximum in the early 1970 s. Therefore, the total petroleum produced is the area under the production curve in Figure 1.

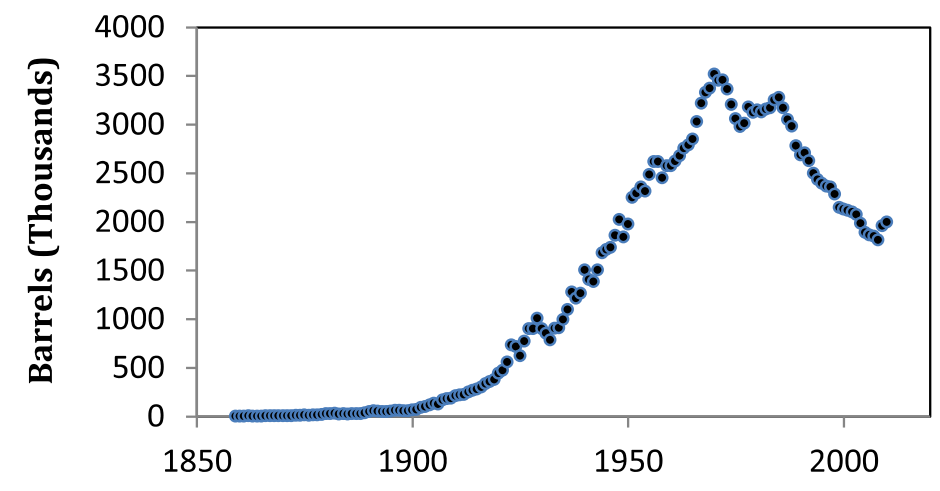

Figure 1: U.S. oil production since 1859.

Making use of the mathematical model and the real data of U.S. oil production, the goal of this project is to estimate the quantity of undiscovered U.S. oil reserves to available to the oil industry in America in the future.

\section{MOTIVATION}

Recently, society has become concerned about the lack of energy resources available to supply the energy needs of large populations. Although renewable energy sources are more environmentally friendly and appropriated to the long-term progress, fossil fuels still play an essential role in most industries. Specifically in America, oil reserves are one of the most important natural resources for the development of the energy industry, transportation, and nearly all manufacturing industries. As petroleum reserves are a finite resource, the undiscovered 
oil reserves in the U.S. are a top priority to the American government, economists, and industrial policy makers ((EIA), Crude Oil Production). With our calculations, we have determined the undiscovered oil reserves of America are about 38 billion barrels, roughly enough for the oil industry to continue at their current pace for ten more years.

\section{MATHEMATICAL DESCRIPTION AND SOLUTION APPROACH}

Since the production curve (Figure 1) has the shape of the graph of an exponential function we fit a model of the form:

$$
y(t)=\frac{A e^{-b(t-c)}}{\left(1+a e^{-b(t-c)}\right)^{2}}
$$

where $y(t)$ gives the annual production of oil (in thousands of barrels) in year $t$, and $A, a, b, c$ are constants.

First, we simultaneously graph the model of the real data and the projected data according to the model depending on the value of the four unknown constants. As each constant plays a significant role in model, we change each constant step by step to attempt to find a good fit for the data. Figure 2 shows the graph of the real data with the projected data we found to be the best fit.

Subsequently, we use SOLVER, an Excel Tool, to minimize the differences of real data by changing our estimated constants. The minimum deviation is calculated by the formula:

$$
\sigma=\min \left\{\sum_{i=1}^{n}\left(y_{\min }\left(t_{i}\right)-y_{i}\right)^{2}\right\}
$$

The determination of the constants $A, a, b$ and $c$ is addressed later in the Discussion section. 


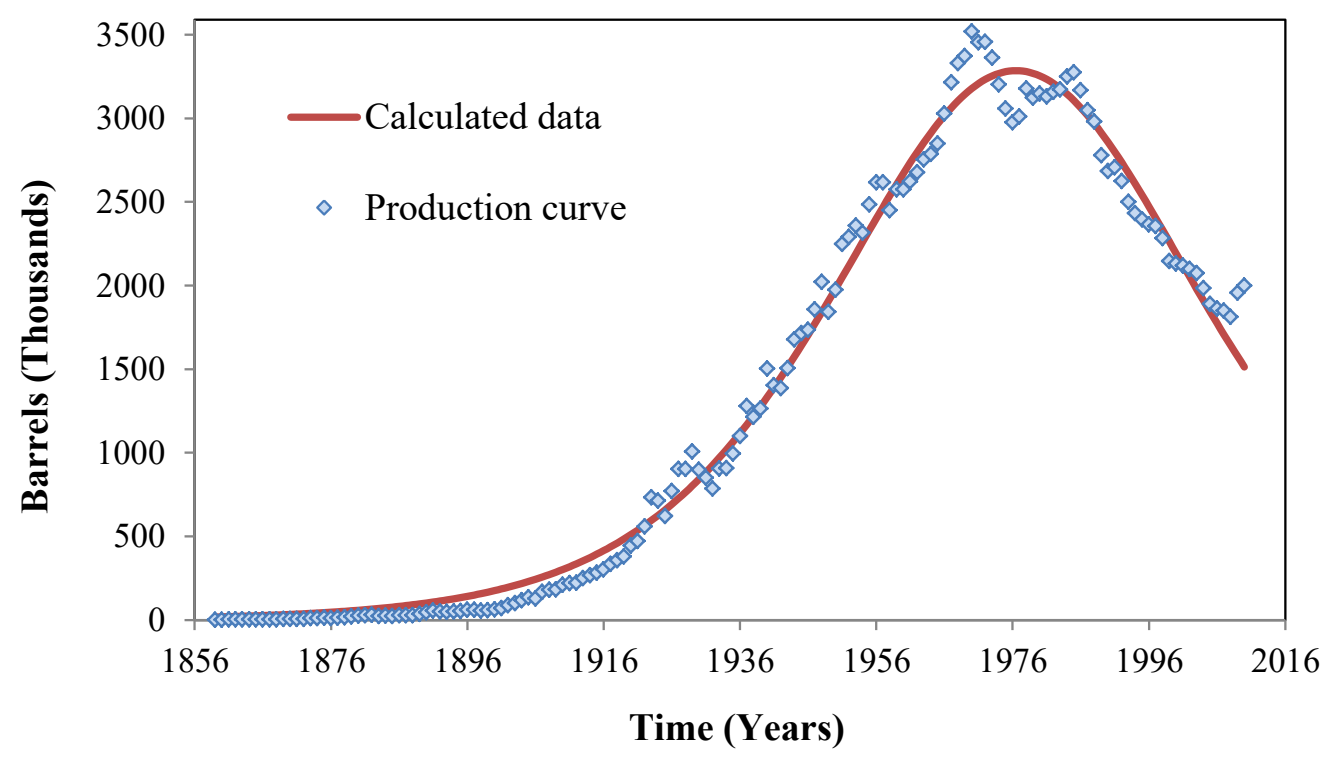

Figure 2: Comparison of our model to the actual U.S. oil production from 1859 to 2010.

To find the year in which the model predicts the peak production of oil, we differentiate (1) to obtain:

$$
y^{\prime}(t)=\frac{e^{-b(t-c)}\left(A a b e^{-b(t-c)}-A b\right)}{\left(1+a e^{-b(t-c)}\right)^{3}}
$$

To find the extreme values of $y(t)$ we set $y^{\prime}(t)=0$. From (3) we see $y^{\prime}(t)=0$ implies:

$$
A a b e^{-b(t-c)}-A b=0
$$

and

$$
t=c+\frac{\ln (a)}{b} .
$$

With the values of our constants (given in the Nomenclature table) (5) gives:

$$
t_{\max }=1977 \text { and } y_{\max }=3,284,390 \text { (thousand barrels). }
$$

Second, we integrate equation (1) to estimate the US petroleum that was once available. Mathematically, integrating the production curve from $-\infty$ to $\infty$ provides the total amount of petroleum, including amount already recovered, known reserves and unknown reserves. 
We calculate:

$$
\int_{-\infty}^{\infty} y(t) d t=\lim _{m \rightarrow-\infty} \int_{m}^{0} y(t) d t+\lim _{m \rightarrow \infty} \int_{0}^{m} y(t) d t
$$

and define:

$$
Y(t)=\frac{A}{a b\left(1+a e^{-b(t-c)}\right)}
$$

Note that $\frac{d}{d t} Y(t)=y(t)$ so $(7)$ becomes:

$$
\lim _{m \rightarrow-\infty}[Y(0)-Y(m)]+\lim _{m \rightarrow \infty}[Y(m)-Y(0)]=\frac{A}{a b} .
$$

Therefore, we obtain the total US petroleum reserves consists of $234,645,178.6$ thousand barrels.

Third, we integrate equation (1) to obtain the total US petroleum that was produced up to the end of 2006. Technically, we integrate the area from $-\infty$ to 2006 to provide the total amount of recovered crude oil through 2006. This is given by:

$$
\int_{-\infty}^{2006} \frac{A e^{-b(t-c)}}{\left(1+a e^{-b(t-c)}\right)^{2}} d t=\lim _{m \rightarrow-\infty}[Y(2006)-Y(m)]=196,904,262
$$

So the total amount of recovered crude oil through 2006 is estimated to be 196,904,262

thousand barrels. However, the oil industry first began to extract crude oil in the year 1859 so for a more realistic estimate we integrate the production curve from 1859 to 2006 :

$$
\int_{1859}^{2006} \frac{A e^{-b(t-c)}}{\left(1+a e^{-b(t-c)}\right)^{2}}=Y(2006)-Y(1859)=196,579,070
$$

Finally, we subtract our value of US oil production from the total reserves to predict the undiscovered US petroleum reserves:

$$
234,645,178.6-196,579,070=38,066,108 \text { (thousand barrels) }
$$

At the end of 2006, the reported US oil reserves totaled 21 billion barrels ((EIA), U.S. Crude Oil, Natural Gas, and Natural Gas Liquids Reserves.); our model prediction is roughly 38 million 
barrels, which is much higher than the reported number. We note that the undiscovered reserves are an unknown quantity so it is quite difficult to evaluate the correct number. For example, USGS predicted the mean conventional Oil Reserves by May, 2011 are 45 billion barrels (Figure 5, Appendix C). Additionally, the U.S. Energy Information Administration's graph shows that the oil reserves are about 48 billion barrels until 2035 (Figure 3).

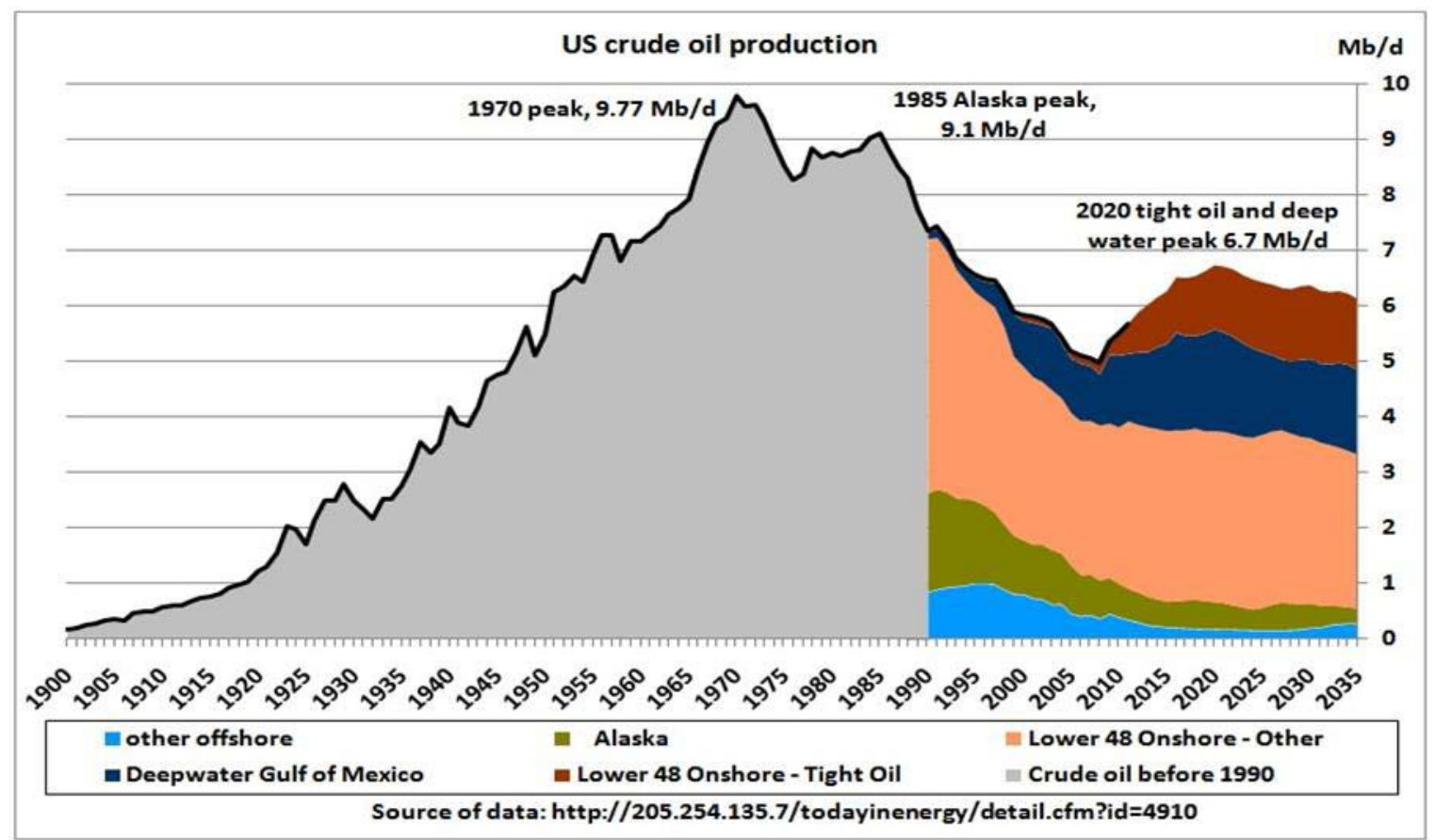

Figure 3: Past and projected U.S. crude oil production by location.

\section{DISCUSSION}

As we have presented the general formula, the detailed equation with real constants will be presented in Appendix B, and the value of the four constants is given in the Nomenclature table. Not only do we try to have the best fit model by minimizing the standard deviation (3); we claim our constants give the best fit for this formula because they yield the minimum summation of the partial derivative with respect to each of the determined constants. (Detailed calculations in Appendix B) 
First we define the residual at each data point $t_{i}$ (see table 2 in the appendix):

$$
E_{i}=y_{i}-\frac{A e^{-b\left(t_{i}-c\right)}}{\left(1+a e^{-b\left(t_{i}-c\right)}\right)^{2}}
$$

Now the sum of the square of the residuals $S_{r}$ is given by:

$$
S_{r}=\sum_{i=1}^{n} E_{i}^{2}=\sum_{i=1}^{n} y_{i}-\frac{A e^{-b\left(t_{i}-c\right)}}{\left(1+a e^{-b\left(t_{i}-c\right)}\right)^{2}}
$$

Differentiating with respect to $A$ yields:

$$
\begin{aligned}
\frac{\partial S_{r}}{\partial A} & =\sum_{i=1}^{n} 2\left[y_{i}-\frac{A e^{-b\left(t_{i}-c\right)}}{\left(1+a e^{-b\left(t_{i}-c\right)}\right)^{2}}\right]\left[-\frac{e^{-b\left(t_{i}-c\right)}}{\left(1+a e^{-b\left(t_{i}-c\right)}\right)^{2}}\right] \\
& =-1.14875 \times 10^{-36} \approx 0
\end{aligned}
$$

Differentiating with respect to $a$ yields:

$$
\begin{aligned}
\frac{\partial S_{r}}{\partial a} & =\sum_{i=1}^{n} 2\left[y_{i}-\frac{A e^{-b\left(t_{i}-c\right)}}{\left(1+a e^{-b\left(t_{i}-c\right)}\right)^{2}}\right]\left[\frac{2 A e^{-2 b\left(t_{i}-c\right)}}{\left(1+a e^{-b\left(t_{i}-c\right)}\right)^{3}}\right] \\
& =1.71127 \times 10^{-74} \approx 0
\end{aligned}
$$

Differentiating with respect to $b$ yields:

$$
\begin{aligned}
\frac{\partial S_{r}}{\partial b} & =\sum_{i=1}^{n} 2\left[y_{i}-\frac{A e^{-b\left(t_{i}-c\right)}}{\left(1+a e^{-b\left(t_{i}-c\right)}\right)^{2}}\right]\left[-\frac{A\left(t_{i}-c\right) e^{-b\left(t_{i}-c\right)}\left(1-a e^{-b\left(t_{i}-c\right)}\right)}{\left(1+a e^{-b\left(t_{i}-c\right)}\right)^{3}}\right] \\
& =-8.4472 \times 10^{-27} \approx 0
\end{aligned}
$$

Lastly differentiating with respect to $c$ yields:

$$
\begin{gathered}
\frac{\partial S_{r}}{\partial c}=\sum_{i=1}^{n} 2\left[y_{i}-\frac{A e^{-b\left(t_{i}-c\right)}}{\left(1+a e^{-b\left(t_{i}-c\right)}\right)^{2}}\right]\left[-\frac{A b e^{-b\left(t_{i}-c\right)}\left(1-a e^{-b\left(t_{i}-c\right)}\right)}{\left(1+a e^{-b\left(t_{i}-c\right)}\right)^{3}}\right] \\
=2.5359 \times 10^{-31} \approx 0
\end{gathered}
$$

We see in (15)-(18) the partial derivative with respect to each of our determined constants is essentially zero, confirming the constants provide a good fit for the data. 


\section{CONCLUSION AND RECOMMENDATIONS}

The entirety of U.S. oil reserves is small enough that the oil industry must be concerned about the most effective strategy to maintain the oil supply in the future. However, the total oil reserves on the planet are predicted to be large enough for the development and needs of high populations over the next several decades. As a result of the oil wells becoming dryer, everyone should be informed about the scarcity of finite resources, especially petroleum in order to save energy resources as much as possible. Saving the precious oil reserves not only aids the longlasting development of modern society, but also helps to protect the environment. 


\section{NOMENCLATURE}

\begin{tabular}{|cll|}
\hline Symbol & \multicolumn{1}{c|}{ Description } & \multicolumn{1}{c|}{ Units } \\
\hline $\boldsymbol{y}(\boldsymbol{t})$ & US oil production & Thousands of barrels/year \\
\hline $\boldsymbol{t}$ & Time & Years \\
\hline $\boldsymbol{A}=\mathbf{3 , 9 4 2 , 0 3 9}$ & Constant & Thousands of barrels \\
\hline $\boldsymbol{a}=\mathbf{0 . 3}$ & Constant & - \\
\hline $\boldsymbol{b}=\mathbf{0 . 0 5 6}$ & Constant & - \\
\hline $\boldsymbol{c}=\mathbf{1 9 9 8}$ & Constant & - \\
\hline
\end{tabular}

\section{REFERENCES}

(EIA), U.S. Energy Information Administration. Crude Oil Production. 19 March 2012.

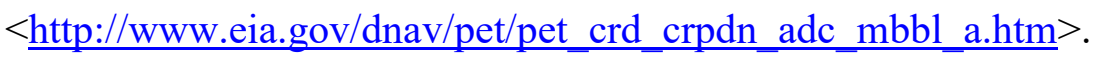

-. U.S. Crude Oil, Natural Gas, and Natural Gas Liquids Reserves. 30 November 2010. $<\underline{\text { http://www.eia.gov/oil_gas/natural_gas/data_publications/crude_oil_natural_gas_reserv }}$ es/cr.html>.

Larson, Ron, Robert Hostetler and Bruce Edwards. Calculus. 8th Edition. Boston, MA: Houghton Mifflin Company, 2005.

"U.S. Geological Survey." October 2007. Mean Conventional Oil Resources. $<$ http://certmapper.cr.usgs.gov/data/noga00/natl/graphic/2007/mean_conv_oil_07.pdf $>$. 


\section{APPENDICES}

\section{APPENDIX A - TABLES}

\begin{tabular}{|c|c|}
\hline Year & $\begin{array}{c}\text { Barrels } \\
\text { (Thousands) }\end{array}$ \\
\hline 1859 & 2 \\
\hline 1860 & 500 \\
\hline 1861 & 2,114 \\
\hline 1862 & 3,057 \\
\hline 1863 & 2,611 \\
\hline 1864 & 2,116 \\
\hline 1865 & 2,498 \\
\hline 1866 & 3,598 \\
\hline 1867 & 3,347 \\
\hline 1868 & 3,646 \\
\hline 1869 & 4,215 \\
\hline 1870 & 5,261 \\
\hline 1871 & 5,205 \\
\hline 1872 & 6,293 \\
\hline 1873 & 9,894 \\
\hline 1874 & 10,927 \\
\hline 1875 & 12,163 \\
\hline 1876 & 91,33 \\
\hline 1877 & 13,350 \\
\hline 1878 & 15,397 \\
\hline 1879 & 199,14 \\
\hline 1880 & 26,286 \\
\hline 1881 & 27,661 \\
\hline 1882 & 30,350 \\
\hline 1883 & 23,450 \\
\hline 1884 & 24,218 \\
\hline 1885 & 21,859 \\
\hline 1886 & 28,065 \\
\hline 1887 & 28,283 \\
\hline 1888 & 27,612 \\
\hline 1889 & 35,164 \\
\hline 1890 & 45,824 \\
\hline 1891 & 54,293 \\
\hline 1892 & 50,515 \\
\hline 1893 & 48,431 \\
\hline 1894 & 49,344 \\
\hline 1895 & 52,892 \\
\hline 1896 & 60,960 \\
\hline
\end{tabular}

\begin{tabular}{|c|c|}
\hline Year & $\begin{array}{c}\text { Barrels } \\
\text { (Thousands) }\end{array}$ \\
\hline 1897 & 60,476 \\
\hline 1898 & 55,364 \\
\hline 1899 & 57,071 \\
\hline 1900 & 63,621 \\
\hline 1901 & 69,389 \\
\hline 1902 & 88,767 \\
\hline 1903 & 100,461 \\
\hline 1904 & 117,081 \\
\hline 1905 & 134,717 \\
\hline 1906 & 126,494 \\
\hline 1907 & 166,095 \\
\hline 1908 & 178,527 \\
\hline 1909 & 183,171 \\
\hline 1910 & 209,557 \\
\hline 1911 & 220,449 \\
\hline 1912 & 222,935 \\
\hline 1913 & 248,446 \\
\hline 1914 & 265,763 \\
\hline 1915 & 281,104 \\
\hline 1916 & 300,767 \\
\hline 1917 & 335,316 \\
\hline 1918 & 355,928 \\
\hline 1919 & 378,367 \\
\hline 1920 & 442,929 \\
\hline 1921 & 472,183 \\
\hline 1922 & 557,531 \\
\hline 1923 & 732,407 \\
\hline 1924 & 713,940 \\
\hline 1925 & 620,373 \\
\hline 1926 & 770,874 \\
\hline 1927 & 901,129 \\
\hline 1928 & 901,474 \\
\hline 1929 & 1007,323 \\
\hline 1930 & 898,011 \\
\hline 1931 & 851,081 \\
\hline 1932 & 785,159 \\
\hline 1933 & 905,656 \\
\hline 1934 & 908,065 \\
\hline
\end{tabular}

\begin{tabular}{|c|c|}
\hline Year & $\begin{array}{c}\text { Barrels } \\
\text { (Thousands) }\end{array}$ \\
\hline 1935 & 993,942 \\
\hline 1936 & $1,098,513$ \\
\hline 1937 & $1,277,653$ \\
\hline 1938 & $1,213,254$ \\
\hline 1939 & $1,264,256$ \\
\hline 1940 & $1,503,176$ \\
\hline 1941 & $1,404,182$ \\
\hline 1942 & $1,385,479$ \\
\hline 1943 & $1,505,613$ \\
\hline 1944 & $1,677,904$ \\
\hline 1945 & $1,713,655$ \\
\hline 1946 & $1,733,424$ \\
\hline 1947 & $1,856,987$ \\
\hline 1948 & $2,020,185$ \\
\hline 1949 & $1,841,940$ \\
\hline 1950 & $1,973,574$ \\
\hline 1951 & $2,247,711$ \\
\hline 1952 & $2,289,836$ \\
\hline 1953 & $2,357,082$ \\
\hline 1954 & $2,314,988$ \\
\hline 1955 & $2,484,428$ \\
\hline 1956 & $2,617,283$ \\
\hline 1957 & $2,616,901$ \\
\hline 1958 & $2,448,987$ \\
\hline 1959 & $2,574,590$ \\
\hline 1960 & $2,574,933$ \\
\hline 1961 & $2,621,758$ \\
\hline 1962 & $2,676,189$ \\
\hline 1963 & $2,752,723$ \\
\hline 1964 & $2,786,822$ \\
\hline 1965 & $2,848,514$ \\
\hline 1966 & $3,027,763$ \\
\hline 1967 & $3,215,742$ \\
\hline 1968 & $3,329,042$ \\
\hline 1969 & $3,371,751$ \\
\hline 1970 & $3,517,450$ \\
\hline 1971 & $3,453,914$ \\
\hline 1972 & $3,455,368$ \\
\hline
\end{tabular}

\begin{tabular}{|c|c|}
\hline Year & $\begin{array}{c}\text { Barrels } \\
\text { (Thousands) }\end{array}$ \\
\hline 1973 & $3,360,903$ \\
\hline 1974 & $3,202,585$ \\
\hline 1975 & $3,056,779$ \\
\hline 1976 & $2,976,180$ \\
\hline 1977 & $3,009,265$ \\
\hline 1978 & $3,178,216$ \\
\hline 1979 & $3,121,310$ \\
\hline 1980 & $3,146,365$ \\
\hline 1981 & $3,128,624$ \\
\hline 1982 & $3,156,715$ \\
\hline 1983 & $3,170,999$ \\
\hline 1984 & $3,249,696$ \\
\hline 1985 & $3,274,553$ \\
\hline 1986 & $3,168,252$ \\
\hline 1987 & $3,047,378$ \\
\hline 1988 & $2,979,123$ \\
\hline 1989 & $2,778,773$ \\
\hline 1990 & $2,684,687$ \\
\hline 1991 & $2,707,039$ \\
\hline 1992 & $2,624,632$ \\
\hline 1993 & $2,499,033$ \\
\hline 1994 & $2,431,476$ \\
\hline 1995 & $2,394,268$ \\
\hline 1996 & $2,366,017$ \\
\hline 1997 & $2,354,831$ \\
\hline 1998 & $2,281,919$ \\
\hline 1999 & $2,146,732$ \\
\hline 2000 & $2,130,707$ \\
\hline 2001 & $2,117,511$ \\
\hline 2002 & $2,097,124$ \\
\hline 2003 & $2,073,453$ \\
\hline 2004 & $1,983,302$ \\
\hline 2005 & $1,890,106$ \\
\hline 2006 & $1,862,259$ \\
\hline 2007 & $1,848,450$ \\
\hline 2008 & $1,811,817$ \\
\hline 2009 & $1,956,596$ \\
\hline 2010 & $1,998,137$ \\
\hline
\end{tabular}

Table 1: Oil Production in the United States from 1859 to 2010. 


\begin{tabular}{|c|c|c|c|c|c|c|}
\hline $\begin{array}{c}\text { Year } \\
\left(t_{i}\right)\end{array}$ & $\begin{array}{c}\text { US Oil } \\
\text { Production } \\
\quad\left(y_{i}\right)\end{array}$ & $\begin{array}{l}\text { Estimated } \\
\text { Production } \\
\left(y\left(t_{i}\right)\right)\end{array}$ & $\frac{\partial y}{\partial A}$ & $\frac{\partial y}{\partial a}$ & $\frac{\partial y}{\partial b}$ & $\frac{\partial y}{\partial c}$ \\
\hline 1859 & 2 & 18,186 & -1.14 E-47 & $7.63 \mathrm{E}-89$ & $-8.95 E-38$ & $2.51 \mathrm{E}-42$ \\
\hline 1869 & 4,215 & 31,771 & -4.19 E-44 & $4.93 \mathrm{E}-85$ & $-3.29 E-34$ & $9.25 \mathrm{E}-39$ \\
\hline 1879 & 19,914 & 55,418 & $-3.47 E-43$ & $7.14 \mathrm{E}-84$ & $-2.70 \mathrm{E}-33$ & $7.65 \mathrm{E}-38$ \\
\hline 1889 & 35,164 & 96,405 & -1.07 E-42 & $3.86 \mathrm{E}-83$ & -8.32 E-33 & $2.37 \mathrm{E}-37$ \\
\hline 1899 & 57,071 & 166,917 & $-3.05 E-42$ & $1.92 \mathrm{E}-82$ & $-2.35 E-32$ & $6.72 \mathrm{E}-37$ \\
\hline 1909 & 183,171 & 286,652 & $-1.71 \mathrm{E}-41$ & $1.89 \mathrm{E}-81$ & $-1.31 \mathrm{E}-31$ & $3.78 \mathrm{E}-36$ \\
\hline 1919 & 378,367 & 485,435 & -6.19 E-41 & $1.20 \mathrm{E}-80$ & $-4.73 E-31$ & $1.37 \mathrm{E}-35$ \\
\hline 1929 & $1,007,323$ & 802,861 & $-2.88 \mathrm{E}-40$ & 9.77 E-80 & $-2.19 E-30$ & $6.37 \mathrm{E}-35$ \\
\hline 1939 & $1,264,256$ & $1,277,124$ & $-6.34 \mathrm{E}-40$ & 3.76 E-79 & $-4.79 E-30$ & $1.40 \mathrm{E}-34$ \\
\hline 1949 & $1,841,940$ & $1,910,155$ & -1.62 E-39 & $1.68 \mathrm{E}-78$ & $-1.22 \mathrm{E}-29$ & 3.57 E-34 \\
\hline 1959 & $2,574,590$ & $2,607,257$ & -3.96 E-39 & $7.18 \mathrm{E}-78$ & $-2.96 \mathrm{E}-29$ & 8.73 E-34 \\
\hline 1969 & $3,371,751$ & $3,144,300$ & -9.07 E-39 & $2.88 \mathrm{E}-77$ & -6.75 E-29 & $2.00 \mathrm{E}-33$ \\
\hline 1979 & $3,121,310$ & $3,268,994$ & $-1.47 \mathrm{E}-38$ & $8.18 \mathrm{E}-77$ & $-1.09 \mathrm{E}-28$ & $3.24 \mathrm{E}-33$ \\
\hline 1989 & $2,778,773$ & $2,913,363$ & $-2.29 E-38$ & $2.23 \mathrm{E}-76$ & $-1.69 \mathrm{E}-28$ & $5.06 \mathrm{E}-33$ \\
\hline 1999 & $2,146,732$ & $2,262,035$ & $-3.10 \mathrm{E}-38$ & $5.28 \mathrm{E}-76$ & $-2.27 \mathrm{E}-28$ & $6.84 \mathrm{E}-33$ \\
\hline \multirow[t]{2}{*}{2009} & $1,956,596$ & $1,576,742$ & $-4.94 \mathrm{E}-38$ & $1.48 \mathrm{E}-75$ & $-3.60 \mathrm{E}-28$ & $1.09 \mathrm{E}-32$ \\
\hline & & Sum: & $-1.15 E-36$ & $1.71 \mathrm{E}-74$ & $-8.45 E-27$ & 2.54 E-31 \\
\hline
\end{tabular}

Table 2: Comparision of the actual US oil production from 1859 to 2009 and the modeled oil production with optimal parameters $\boldsymbol{A}, \boldsymbol{a}, \boldsymbol{b}$, and $\boldsymbol{c}$. 


\section{APPENDIX B - CALCULATIONS}

With $A=3942039, a=0.3, b=0.056, c=1998$, we have:

$$
y(t)=\frac{3942039 e^{-0.056(t-1998)}}{\left(1+0.3 e^{-0.056(t-1998)}\right)^{2}}
$$

Thus the models derivative is:

$$
\begin{gathered}
\frac{d y}{d t}=\frac{-220754.184 e^{-0.056(t-1998)}+66226.2552 e^{-2 \times 0.056(t-1998)}}{\left(1+0.3 e^{-0.056(t-1998)}\right)^{3}} \\
\frac{d y}{d t}=\frac{e^{-0.056(t-1998)}\left(-220754.184+66226.2552 e^{-0.056(t-1998)}\right)}{\left(1+0.3 e^{-0.056(t-1998)}\right)^{3}} \\
\begin{array}{c}
\frac{d y}{d t}=0 \Leftrightarrow e^{-0.056(t-1998)}\left(-220754.184+66226.2552 e^{-0.056(t-1998)}\right) \\
\Leftrightarrow\left(-220754.184+66226.2552 e^{-0.056(t-1998)}\right)=0
\end{array}
\end{gathered}
$$

Thus:

$$
e^{-0.056(t-1998)}=\frac{1}{0.3}
$$




\section{$\underline{\text { APPENDIX C - FIGURES }}$}

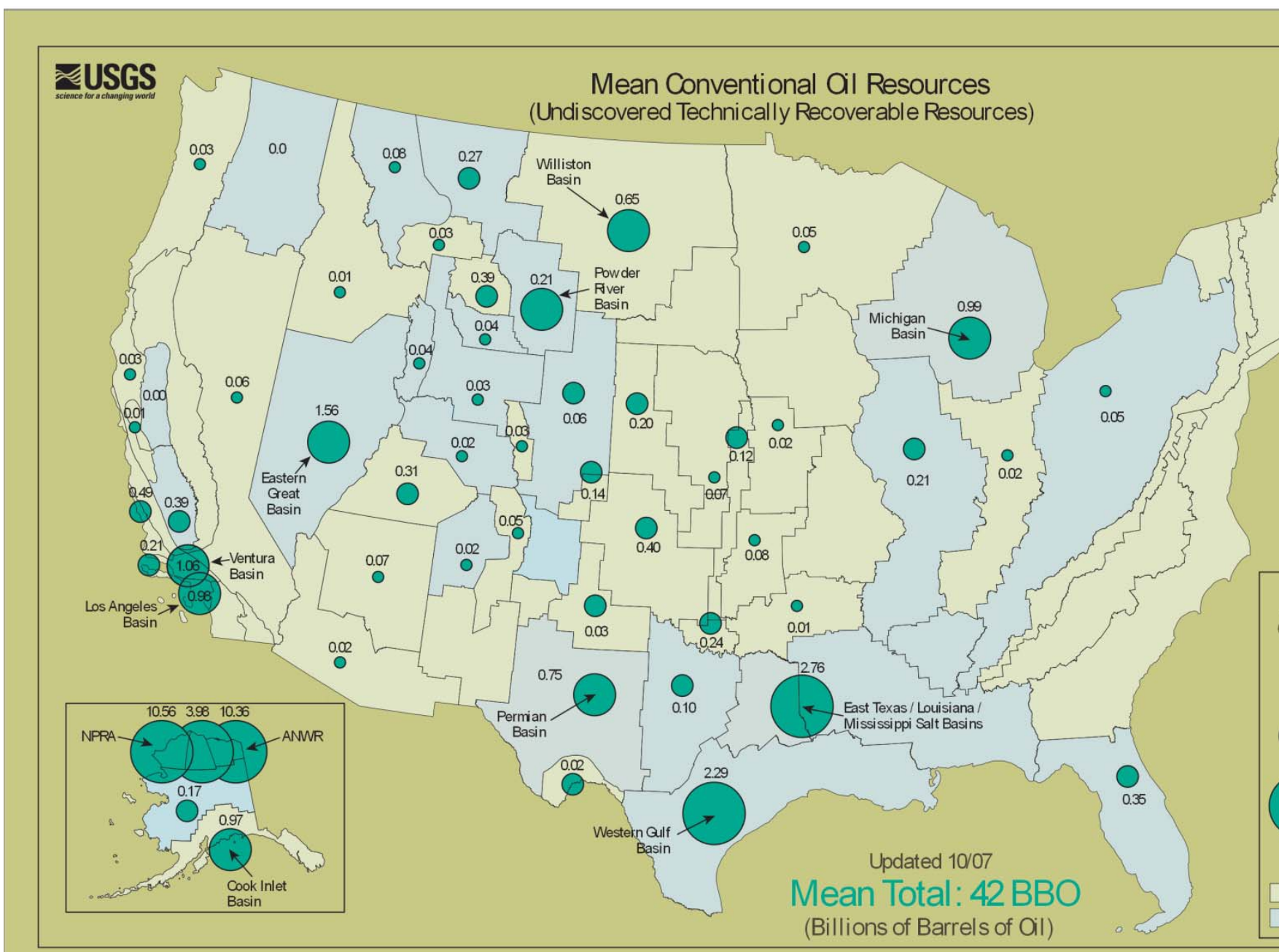

Figure 4: Mean conventional oil resources by location as of October 2007. (U.S. Geological Surve 